\title{
MENCIPTAKAN BELAJAR YANG HUMANIS TANTANGAN PENDIDIK YANG PROFESIONAL DAN BERKARAKTER
}

\author{
Siti Irene Astuti Dwiningrum \\ Fakultas Ilmu Pendidikan, Universitas Negeri Yogyakarta \\ ireneast@yahoo.com
}

\begin{abstract}
Abstrak
Dehumanisasi pendidikan merupakan fenomena sosial dalam proses pendidikan dan pembelajaran di sekolah. Perilaku kekerasan di sekolah oleh guru kepada siswa, pelecehan seksual, tindakan bullying antar siswa, tawuran antar pelajar, penggunaan media sosial yang tidak terkontrol oleh pendidikan, dan praktik aborsi di kalangan pelajar merupakan ragam gejala dehumanisasi pendidikan yang sangat memprihatinkan. Sistem pendidikan cenderung memaksa peserta didik mengembangkan kekuatan kognitif, dan kurang mengembangkan moralitas dan karakter peserta didik. Sistem belajar kurang mengembangkan potensi manusia secara optimal sesuai dengan eksistensi sebagai manusia yang ingin belajar digambarkan sebagai whole-personlearning, dengan pribadi yang utuh menghasilkan perasaan memiliki (feeling of belonging) pada diri peserta didik. Sekolah harus dibangun berdasarkan prinsip-prinsip pendidikan humanis. Belajar yang humanis dapat diwujudkan oleh guru-guru yang mempunyai kemampuan untuk menerapkan prinsip-prinsip pendidikan humanis dalam mengajar di kelas dan mampu untuk menjalankan multiperannya sebagai pendidik profesional. Akuntabilitas profesional diperlukan bagi guru untuk mencerminkan kompetensi dan integritas pendidik yang profesional dan berkarakter.
\end{abstract}

Kata kunci:

\section{CREATING HUMANISTIC LEARNING A CHALLENGE TO PROFESSIONAL TEACHERS WITH HIGH CHARACTER}

Siti Irene Astuti Dwiningrum

Fakultas Ilmu Pendidikan, Universitas Negeri Yogyakarta ireneast@yahoo.com

\begin{abstract}
Dehumanization in education is an example of social phenomena existing in the process of character education in schools. Violation done by the teacher to the students, sexual abuse, bullying among students, students' riot, social media misuse, and abortion cases are examples of worrying phenomena related to dehumanization in education. The educational system tends to force the students to maximize their cognitive potentials by neglecting the importance of their moral and character education. The system is not, merely, helping the students to optimize their potentials which may be described as whole-person learning, having the sense of belonging. The schools should have been built by considering the values of humanity. Humanistic learning can be realized by the teachers having credentials to apply the values of humanity in the classroom. The professional accountability is also required to create teachers who are capable of showing their professional competence and integrity.
\end{abstract}

Keywords: 



\section{PENDAHULUAN}

Sistem pendidikan nasional belum mencerminkan wajah yang humanis karena pembangunan pendidikan belum menciptakan manusia yang berkembang potensinya secara optimal. Sistem pendidikan nasional belum menghasilkan manusia sebagaimana diamanatkan oleh Undang-undang Dasar 1945. Pendidikan cenderung tidak lagi menghormati dan menghargai martabat manusia dan segala hak asasinya. Proses pendidikan cenderung kurang menumbuhkan nilai-nilai kemanusiaan dalam diri peserta didik, karena sistem pendidikan memaksa peserta didik dalam kekuatan kognitif yang kurang mengembangkan perkembangan peserta didik secara optimal dari segi afeksi, dan melemahnya penanaman nilai etika dan estetika serta karakter dalam diri peserta didik.

Dehumanisasi pendidikan terus meningkat di lingkungan keluarga, sekolah dan masyarakat. Dalam keluarga KDRT, kekerasan seksual dan verbal terus meningkat, "broken home" yang menyebabkan problem anak terus bertambah, perceraian dan kegagalan sosialisasi dst. terus terjadi dalam semua lapisan masyarakat. Peran media massa semakin kuat dalam membentuk sikap dan perilaku pesersta didik yang kurang mendidik. Media massa menajdi sumber informasi terkini dan sekaligus menjadi sumber masalah dalam proses belajar peserta didik. Tayangan dan progam TV sebagai contohnya kurang mendidik, bahkan membentuk perilaku budaya "instant". Fungsi TV menggeser fungsi orangtua sebagai "teman" bagi anak. Nasehat dari orangtua kadang menjadi tidak efektif karena pengaruh media $\mathrm{TV}$ atau media sosial lainnya. Hubungan orangtua-anak semakin melemah karena berbagai alasan pragmatis. Demikian halnya, kelekatan emosional cenderung melemah, karena hubungan cenderung bersifat teknis menjadi dasar hubungan sosial dalam mencapai tujuan tertentu (Dwiningrum, 2014).

Kehidupan sekolah belum seluruhnya mampu menjadikan siswa merasa "fun" untuk belajar. Beban matapelajaran, perubahan kurikulum yang tidak "siap" dilakukan oleh guru menjadi kendala bagi sekolah untuk menata fondasi kehidupan yang humanis. Perilaku kekerasan di sekolah oleh guru kepada siswa, pelecehan seksual, tindakan " bullying" antar- siswa, tawuran antar pelajar, penggunaan media sosial yang tidak terkontrol oleh pendidikan, praktik aborsi di kalangan pelajar merupakan ragam gejala dehumanisasi pendidikan yang sangat memprihatikan. Dehumanisasi pendidikan terus terjadi dalam proses pendidikan di Indonesia. Sistem pendidikan nasional belum memberikan kesempatan pada peserta didik untuk mengembangkan potensi dirinya secara optimal. Fenomena sosial tersebut membuktikan bahwa telah terjadi perubahan orientasi pendidikan cenderung sebagai komoditas kekuasaan dan kepentingan bisnis dari para kapitalis pendidikan.

Politisasi dalam pendidikan memperkuat sistem pendidikan yang tidak humanis. Sebagai contohnya, kebijakan perubahan kurikulum selalu terkait dengan perubahan dan kepentingan para penguasa. Kurikulum seringkali berubah bukan didasarkan pada tujuan substansinya, tetapi lebih pada tujuan politik penguasa pendidikan untuk berperan dalam pembangunan pendidikan dengan mem-buat kebijakan yang baru. Kebijakan Ujian Nasional seringkali didasarkan pada tujuan "ganda" yang kurang memperhatikan kebu-tuhan peserta untuk termotivasi belajar dengan senang menghadapi ujian. Sebagai konsekuensinya perilaku stress cenderung dialami oleh siswa, guru dan orangtua setiap menghadapi UN karena ditargetkan lulus ujian. Bahkan ada kecenderungan ujian nasional adalah "event" yang menakutkan bagi siswa karena kelulusan ujian nasional adalah sama dengan "eksekusi" dinilai berhasil atau gagal sekolah; di samping itu bagi sekolah kelulusan peserta didiknya adalah simbol keberhasilan sekolah. Sebagai dampaknya, sekolah berupaya untuk membangun budaya belajar yang kuat dan tersistimatis dengan sistem pelatihan soal ujian yang kadang membosankan, di sisi lain praktik ketidak jujuran juga dilakukan oleh sekolah yang tidak mampu membangun budaya belajar yang kuat di sekolah. Proses belajar yang panjang kadang menjadi hilang maknanya ketika siswa dan guru disibukkan untuk keberhasilan ujian nasional. Upaya pemerintah untuk mengkaji kembali ujian nasional masih "pro" dan "kontra", hal ini menunjukkan bahwa tidak mudah untuk membangun kualitas pendidikan yang humanis. Polemik tentang pelakasanaan UN perlu untuk diatasi secara bijaksana agar kualitas pendidikan tetap menjadi tujuan 
dalam pembangunan pendidikan, tanpa harus mengorbankan eksistensi peserta didik dalam mengembangkan berbagai bakat dan potensinya, sehingga anak lebih berkembang menjadi manusia yang mandiri dan percaya diri, sehingga tindakan anarkhis dapat diminimalisir.

Demikian juga, krisis karakater bangsa berdampak pada dunia pendidikan. Guru menghadapi tantangan yang sangat berat untuk menanamkan nilai-nilai karakter pada peserta didik. Di samping itu, pendidik mempunyai tugas yang semakin besar untuk mengembangkan proses belajar yang membentuk perilaku jujur, karena proses pembelajaran cenderung mengajarkan pendidikan moral dan budi pekerti sebatas teks dan kurang dipersiapkan pada siswa untuk menyikapi dan menghadapi kehidupan yang kontradiktif. Penyelenggaraan pendidikan cenderung terfokus pada pengembangan aspek kognitif sedangkan aspek soft skills atau nonakademik sebagai unsur utama pendidikan karakter belum diperhatikan secara optimal bahkan cenderung diabaikan. (Raka, 2006).

Dehumanisasi pendidikan semakin kompleks. Perilaku sosial yang cenderung kearah menghancurkan diri bangsa kita sendiri (act of self distruction) Ketika bangsa-bangsa lain bekerja keras mengerahkan potensi masyarakatnya untuk meningkatkan daya saing negaranya, sebagian dari warga di Indonesia cenderung bersemangat memakai energi masyarakat untuk mencabik-cabik dirinya sendiri, dan sebagian besar yang lain terkesan membiarkannya. Memecahkan perbedaan pendapat atau pandangan dengan menggunakan kekerasan, yang secara sistematik mengobarkan kebencian untuk memicu konflik horizontal atas dasar SARA, dan menteror bangsa sendiri. Hal ini terjadi karena makin memudarnya nilai-nilai kemanusiaan yang mencakup semangat dan kesediaan untuk bertumbuh kembang bersama, secara damai dalam kebhinekaan (Raka, 2007, p. 2 dalam Dwiningrum 2010, 2012, 2013). Sekolah semakin tidak mampu menunjukkan perannya sebagai kekuatan untuk membentuk pribadi berbudaya, bermartabat dan berkarakter.

Dehumanisasi pendidikan bersifat multidimensional. Dehumanisasi pendidikan disebabkan berbagai faktor antara lain: a) krisis karakter bangsa terjadi dalam dunia pendidikan; b) aktivitas kelembagaan pendidikan yang pragmatis materialistikl c) perilaku sosial yang cenderung ke arah menghancurkan diri bangsa kita sendiri (act of self distruction); d) ketidakadilan dalam proses pendidikan sebagai gejala dehumanisasi struktural; e) arogansi kekuasaan yang menghambat kreativitas dan kebebasan peserta didik untuk berekspresi, f) mentalitas lemah dan tidak memiliki kemandirian; g) melemahnya hubungan sosial karena perkembangan teknologi menyebabkan alienasi (Dwiningrum, 2014)

Dehumanisasi pendidikan harus diatasi secara komprehensif dengan membangun fondasi pendidikan yang humanis. Belajar sebagai aktivitas pokok dalam kehidupan manusia harus dikembalikan pada fungsi sosial dan pendidikan untuk membangun manusia yang mampu berkembang potensi diri secara optimal sesuai dengan eksistensi sebagai manusia yang ingin belajar. Fondasi pendidikan yang humanis harus diletakan kembali dalam membangun kebijakan pendidikan yang humanis. Guru sebagai ujung tombak yang menyentuh siswa untuk belajar haruslah menjadi manusia yang memiliki karakter yang kuat dan profesional dalam mengembangkan pendidikan yang humanis di sekolah. Makalah ini akan memaparkan tiga hal pokok yang apa makna belajar, bagaimana budaya sekolah humanis? dan bagaimana guru yang mampu mengajar secara profesional dan berkarakter untuk menanamkan pendidikan yang humanis di kelas?

\section{PEMBAHASAN}

\section{Makna Belajar}

Perkembangan kehidupan manusia pada dasarnya tidak terlepas dari proses kegiatan belajar-mengajar, baik dalam proses pendidikan formal, informal maupun non-formal. Belajar secara sederhana adalah proses perubahan yang terjadi dalam diri seseorang yang ditujukkan dengan adanya perubahan perilaku. Belajar adalah sebuah proses perubahan di dalam kepribadian manusia dan perubahan tersebut ditampakkan dalam bentuk peningkatan kualitas dan kuantitas tingkah laku seperti peningkatan kecakapan, pengetahuan, sikap, kebiasaan, pemahaman, ketrampilan.

Balajar memiliki banyak makna. Sebagaimana dijelaskan oleh Hakim (2005, p.1), belajar adalah suatu proses perubahan di dalam kepribadian manusia, dan perubahan ter- 
sebut ditampakkan dalam bentuk peningkatan kualitas dan kuantitas tingkah laku seperti peningkatan kecakapan, pengetahuan, sikap, kebiasaan, pemahaman, keterampilan, daya pikir, dan lain-lain kemampuan. Menurut Slameto (2003, p.13), belajar merupakan suatu proses usaha yang dilakukan seseorang untuk memperoleh suatu perubahan tingkah laku yang baru secara keseluruhan, sebagai hasil pengalamannya sendiri dalam interaksi dengan lingkungannya. Menurut Skinner dalam Dimyati \& Mudjiono (1999, p. 9), belajar merupakan hubungan antara stimulus dan respons yang tercipta melalui proses tingkah laku.

Belajar adalah sebuah proses perubahan di dalam kepribadian manusia yang tercermin dalam bentuk peningkatan kualitas dan kuantitas tingkah laku seperti peningkatan kecakapan, pengetahuan, sikap, kebiasaan, pemahaman, ketrampilan, daya pikir, dan kemampuan-kemampuan yang lain.

Belajar adalah proses mendidik. Bagi John Dewey ada hubungan antara masyarakat dan pendidikan. Proses mendidik terjadi secara informal ketika orang dewasa di dalam suatu pergaulan dan memperoleh ketrampilan membaca, dan pengetahuan umum untuk hidup berkelompok. Dalam arti sekolah formal, pendidikan adalah proses yang disengaja membawa orang yang belum matang, ke dalam partisipasi budaya dengan menyediakan alat simbolik dan linguistik yang dibutuhkan untuk interaksi kelompok dan komunikasi.

Belajar dapat dikaji dalam dua dimensi. Jika dikaitkan dengan konsep pendidikan Dewey memiliki dimensi konservatif dan rekonstruktif. Pendidikan yang presentative atau konservatif ketika mempertahankan kesinambungan budaya dengan menyalurkan warisan dari orang dewasa kepada anggota kelompok belum matang yakni anak-anak. Dalam kelompok aspek formal dan informal, pendidikan selalu merupakan proses sarat nilai yang melibatkan pengaruh budaya, karena itu terjadi dalam kontek kebudayaan tertentu dengan adat istiadat yang unik, folkways, dan konteks bahasa. Meskipun pengaruh budaya terkait dengan waktu dan ruang, tetapi menyediakan sarana komunikasi dan ekspresi dimana individu membebaskan dirinya melalui partisipasi kelompok. Sebagai transmisi budaya, pendidikan adalah sarana kelompok mereproduksi jenis budaya dan dengan demikian melang- gengkan budayanya. Menurut Dewey, anak tidak lahir dengan sifat-sifat khas manusia, sifat-sifat manusia tersebut diperoleh atau dipelajari sebagai asosiasi anak dengan kelompok. Proses pendidikan adalah alat dimana, kelompok mentransmisikan ketrampilan budaya, pengetahuan, dan nilai-nilai yang diperlukan untuk memproduksi jenis budaya yang diingankan dan dengan demikian mengabadikan warisan (Dewey dalam Manan 2011).

Belajar adalah proses yang dinamis. Bagi Dewey pendidikan juga sebagai proses dinamis. Sebagai warisan budaya dikenakan pada kaum muda, cara mengubah juga disediakan. Dunia dipandang sebagai alam semesta dalam perubahan konstan. Dengan menggunakan metode ilmiah, manusia memiliki kemungkinan untuk menggunakan proses perubahan. Budaya tidak dipahami sebagai entitas statis melainkan hal yang dinamis dan berorientasi proses sosial yang bergerak secara dinamis.

Belajar membutuhkan kekuatan dalam diri manusia. Belajar akan sulit dilakukan ketika tak ada lagi kekuatan yang muncul dalam diri individu. Bahkan belajar adalah akvitas paling dasar yang dibutuhkan sepanjang hidup manusia. Makna manusia yang sesungguhnya ketika ada nafas untuk selalu belajar. Bagi manusia, belajar adalah sebuah kesadaran yang tinggi selalu berpikir tentang hidup dan keinginan dalam hidupnya. Belajar membutuhkan konsep yang jelas agar hasilnya dapat bermanfaat bagi kehidupan manusia . Konsep pendidikan humanis telah menyadarkan pada semua orang bahwa peserta didik adalah subyek yang harus dikembangkan potensi dan eksistensinya melalui belajar. Belajar menjadi "spirit" individu untuk secara terus-mnerus untuk menyadari dirinya untuk belajar tentang berbagai ilmu pengetahuan yang bermanfaat bagi kehidupannya .

Konsep belajar terus dikembangkan oleh para ahli pendidikan. Teori belajar terus berkembang, Perdebatan antar ahli pendidikan membuktikan bahwa belajar menjadi diskusi yang tak pernah henti. Teori belajar behavioristik menjelaskan bahwa belajar adalah perubahan dalam tingkah laku sebagai akibat dari interaksi antara stimulus dan respons. Belajar adalah perubahan yang dialami siswa dalam hal kemampuannya untuk bertingkah laku dengan cara yang baru sebagai hasil interaksi antara stimulus dan respons Teori ini 
lalu berkembang menjadi aliran psikologi belajar yang berpengaruh terhadap arah pengembangan teori dan praktik pendidikan dan pembelajaran yang dikenal sebagai aliran behavioristik. Aliran ini menekankan pada terbentuknya perilaku yang tampak sebagai hasil belajar. Teori behavioristik dengan model hubungan stimulus-responsnya, mendudukkan orang yang belajar sebagai individu yang pasif. Respons atau perilaku tertentu dengan menggunakan metode pelatihan atau pembiasaan semata. Munculnya perilaku akan semakin kuat bila diberikan penguatan dan akan menghilang bila dikenai hukuman. Belajar merupakan akibat adanya interaksi antara stimulus dan respons. Seseorang dianggap telah belajar sesuatu jika dia dapat menunjukkan perubahan perilakunya. Menurut teori ini dalam belajar yang penting adalah input yang berupa stimulus dan output yang berupa respons. Stimulus adalah apa saja yang diberikan oleh guru tersebut. Teori ini mengutamakan pengukuran, sebab pengukuran merupakan suatu hal penting untuk melihat terjadi atau tidaknya perubahan tingkah laku tersebut.

Konsep belajar dari perspektif konstruktivisme bahwa pengetahuan tumbuh dan berkembang melalui pengalaman. Pemahaman berkembang semakin dalam dan kuat apabila selalu diuji oleh berbagai macam pengalaman baru. Menurut Piaget, pada saat manusia belajar telah terjadi dua proses dalam dirinya, yaitu proses organisasi dan proses adaptasi. Proses organisasi adalah proses ketika manusia menghubungkan informasi yang diterima dengan struktur pengetahuan yang sudah ada sebelumnya. Melalui proses ini, manusia dapat memahami informasi yang baru didapat, dengan menyesuaikan informasi tersebut dengan struktur pengetahuan yang dimilikinya. Proses adaptasi berisi dua kegiatan: a) menggabungkan pengetahuan yang diterima (asimilasi); b) mengubah struktur pengetahuan yang dimiliki dengan struktur pengetahuan yang baru, sehingga terjadi equilibrium. Dalam proses adaptasi ini, Piaget mengemukakan empat konsep dasar : (a) skemata, yaitu kumpulan konsep atau kategori yang digunakan individu ketika ia berinteraksi dengan lingkungan; (b) asimilasi, yaitu proses kognitif dan penyerapan pengalaman baru ketika seseorang memadukan stimulus atau persepsi ke dalam skemata atau perilaku yang sudah ada; (c) akomodasi, yaitu proses struktur kognitif yang ber- langsung sesuai dengan pengalaman baru. Proses tersebut menghasilkan terbentuknya skemata baru dan berubahnya skemata lama; d) Equilibrium, yaitu pengaturan diri untuk mengatur keseimbangan proses asimilasi dan akomodasi (Salkind, 2004, pp. 311-321).

Pendidikan tidak dapat dilepaskan dari kebudayaan dan hanya dapat terlaksana dalam suatu komunitas masyarakat. Teori sosiokultural menekankan bagaimana seorang anak atau pembelajar menyertakan kebudayaan ke dalam penalaran, interaksi sosial, dan pemahaman diri mereka. Santrock (2009: p. 323) mengemukakan bahwa dalam teori sosiokultural atau kognitif sosial (teori cognitivei theory) yang berperan penting dalam pembelajaran ialah faktor sosial, kognitif, serta perilaku anak. Faktor-faktor kognitif meliputi harapan siswa untuk berhasil sedangkan faktor sosial meliputi pengamatan siswa terhadap perilaku pencapaian orangtua mereka.

Dari ketiga teori di atas dapat disimpulkan bahwa konsep yang dikembangkan masing-masing memiliki kelebihan dan kekurangan dalam menganalisis belajar sebagai bagian dari proses sosial yang dialami oleh manusia untuk menjadi pribadi yang mandiri. Teori yang berbeda dalam memahami dan menganalisis belajar akan membawa pengaruh pada hasil yang hendak dicapai dalam proses belajar. Analisis kritis terhadap eksistensi teori tersebut terus terjadi dalam lembaga pendidikan yang akan memilih dan menerapkan proses belajar-mengajar di sekolah. Dalam konteks inilah, pemahaman tentang konsep pendidikan yang digunakan sebagian landasan konseptual dalam membangun fondasi pendidikan menjadi aspek penting. Karena konsep belajar sangat membutuhkan rujukan idiologis yang menjadi dasar agar tujuan pendidikan secara substansi tepat dalam mengatasi masalah pendidikan. Bagi lembaga pendidikan yang saat ini sedang menghadapi dehumanisasi pendidikan maka fondasi konssep pendidikan humanis menjadi penting untuk dikaji kembali. Dalam bukunya Freedom To Learn (1994), Carl Rogers mendeskripsikan prinsip-prinsip dasar humanistik : a) Manusia mempunyai kemampuan untuk belajar selama alami; b) Belajar yang signifikan terjadi apabila materi pelajaran dirasakan murid mempunyai relevansi dengan maksud-maksud; c) Belajar yang menyangkut perubahan di dalam persepsi dirinya sendiri 
dianggap mengancam dan cenderung untuk ditolaknya; d) Tugas-tugas belajar yang mengancam diri ialah lebih mudah dirasakan dan diasimilasikan apabila ancamana-ancaman dari luar semakin kecil; e) Apabila ancaman terhadap dirinya rendah, pengalaman dapat diperoleh dengan berbagai cara yang berbedabeda dan terjadilah proses belajar; f) Belajar yang bermakna diperoleh siswa dengan melakukannya; g) Belajar lancar bilamana siswa dilibatkan dalam proses belajar dan ikut bertanggung jawab terhadap proses belajar itu; $h$ ) Belajar inisiatif sendiri yang melibatkan pribadi siswa seutuhnya,baik perasaan maupun intelek, merupakan cara yang dapat memberikan hasil yang mendalam dan lestari; i) Kepercayaan terhadap diri sendiri, kemerdekaan, kreativitas, lebih mudah dicapai terutama jika siswa dibiasakan untuk mawas diri dan mengkritik dirinya sendiri dan penilaian dari orang lain merupakan cara kedua yang penting; j) Belajar yang paling berguna secara social di dalam dunia modern ini adalah belajar mengenai proses belajar, suatu keterbukaan yang terus-menerus terhadap pengalaman dan penyatuannya ke dalam diri sendiri mengenai proses perubahan itu sendiri.

\section{Budaya Sekolah Humanis}

Sekolah memiliki peran penting dalam dinamika kehidupan masyarakat. Kajian tentang sekolah terus berkembang. Eksistensi sekolah karena beberapa fungsi sosial. Fungsi sosial terus dipertahankan, karena sekolah mempunyai peran penting dalam menjaga ketertiban dalam kehidupan sosial. Sekolah mempunyai peran penting dalam proses sosialisasi masyarakat, baik secara personal maupun sosial. Sekolah dibutuhkan untuk menjaga keberlangsungan kehidupan yang tertib. Sebagaimana dijelaskan oleh Durkheim, sekolah sebagai institusi yang bertanggung jawab atas sosialisasi generasi muda, bertujuan agar menumbuhkan dan mengembangkan dalam diri anak, sejumlah kondisi fisik, intelektual dan moral yang dituntut oleh masyarakat politis secara keseluruhan dan lingkungan khusus dimana dia berada (Sastrapratedja, 1999, p. 2).

Dewey berusaha untuk mendirikan sekolah sebagai miniatur komunitas atau embrio masyarakat. Meskipun percaya bahwa masyarakat terpisah-pisah, manusia makhluk individu, ia menolah kompetitif atomisme sosial yang dianjurkan oleh Spencer dan
Summer. Menurut Dewey, manusi tinggal di sebuah lingkungan sosial yang baik serta lingkungan fisik. Bekerja keras untuk tinggal, manusia bertemu, asosiasi manusia, secara efektif menggapai kesejahteraan sosial untuk survival, memperkaya pengalaman, meningkatkan kemampuan pemecahan masalah. Bagi Dewey, hidup melibatkan kemampuan untuk memecahkan masalah sehingga akan memudahkan hidup. Jika hidup dalam arti luas ditafsirkan sebagai pemecahan masalah maka metodologi pendidikan belajar tentang bagaimana pemecahkan masalah. Karena interaksi dengan lingkungan merupakan proses transaktif yang berubah baik organisme mengalami pengalaman dan pendidikan sebagai pemecahan masalah yang dapat didefinisikan secara luas sebagai suatu pengalaman yang mengubah keyakinan dan sikap dan yang membuat orang berbeda dari sebelum dia memiliki pengalaman (Dewey dalam Manan 2011).

Menurut Dewey, sekolah adalah lingkungan yang khusus didirikan untuk enculture kaum muda dengan sengaja membawa mereka ke dalam partisipasi budaya. Sebagai lembaga sosial, sekolah adalah bada selektif yang mentransmisikan partsipasi budaya dan berusaha untuk merekonstruksi aspek-aspek lain dari warisan budaya. Tiga fungsi sekolah yaitu menyederhanakan, memurnikan, menyeimbangkan warisan budaya. Sekolah memiliki unsur-unsur dari warisan dan mengurangi kompleksitas mereka kedalam unit sesuai dengan untuk belajar, berdasarkan waktu, pelajarm dan kesiapan. Sebagai lembaga memurnikan, sekolah memiliki elemen tertentu dari warisan budaya dan menghilangkan aspek yang tidak layak yang membatasi pertumbuhan manusia, aspek lingkungan tidak layak akan diizinkan untuk mempengaruhi pembentukan karakter anak muda. Menyeimbangkan integrasi pengalaman yang telah dipilih dan dimurnikan menjadi totalitas harmoni (Dewey dalam Manan 2011).

Sekolah mengajarkan tentang nilainilai pokok yang dibutuhkan daam membangun kepercayaan dan keyakinan serta ketrampilan sosial. Sebagaimana dijelaskan Durkheim dan Parsons anggota masyarakat perlu memperoleh seperangkat kepercayaan, pengetahuan dan nilai yang sama untuk mempertahankan kohesi dan kesatuan social. Pandangan Talcott Parsons terhadap fungsi sekolah adalah (1) Sekolah berfungsi sebagai 
sarana sosialisasi utama, (2) sekolah berfungsi sebagai seleksi dan alokasi tenaga kerja, dan (3) Sekolah berfungsi memberikan kesempatan yang sama. Sebagai sarana sosialisasi, Parsons melihat dua fungsi dari sekolah; pertama, mengarahkan anak dari orientasi kekhususnya (terbatas) ke orientasi universalistis (umum) dan dari orientasi askriptif (sesuatu yang didapat bukan dengan usaha) keprestasi; kedua, alokasi seleksi atau diferensi ke peranperan orang dewasa.

Sekolah mempunyai peran penting dalam proses sosialisasi utama dalam mengembangkan komitmen dan kapasitas peserta didik yang diperlukan dalam kehidupan. Parsons mengakui bahwa ada sarana lain yang terlibat dalam proses sosialisasi, termasuk keluarga dan lembaga lain, tetapi sekolahlah yang merupakan sarana sosialisasi utama, terutama dalam fungsinya mensosialisasikan individu ke berbagai komitment dan kapasitas yang merupakan syarat esensial dari kegiatan dan peran mereka kemudian hari. Komitmen itu adalah komitmen: (1) terhadap nilai-nilai yang ada dalam masyarakat dan (2) terhadap peran tertentu di dalam struktur sosial.

Sekolah mempunyai peran yang strategis dalam belajar. Karena sekolah mempunyai berbagai fungsi sosial yang ditujukan untuk membantu individu mengembangkan potensi dirinya dengan optimal. Keberhasilan dalam menyelenggarakan pendidikan yang humanis ditentukan oleh penerapan prinsip pendidikan humanis dalam menyelenggarakan pendidikan di sekolah. Pendidikan humanis akan sulit dilaksanakan, jika sekolah tidak mampu untuk mengkodisikan budaya sekolah yang mendukung prinsip pendidikan humanis dapat diterapkan secara optimal. Beberapa prinsip dasar pendidikan yang humanis antara lain: (a) prinsip pendidikan berpusat pada anak. Guru tidak bersifat otoriter, namun memperhatikan keterlibatan dan aktivitas anak. Pendidikan dilaksanakan secara kooperatif dan demokratis; (b) siswa adalah manusia aktif, bukan pasif. Anak akan belajar dengan aktif bila memahami akan kebutuhannya, dan sesuai dengan bakat, minat dan kemampuannya; (c) peran guru sebagai pembimbing, motivator, penasehat, bukan penguasa kelas. Tugas guru membantu siswa untuk belajar, sehingga memiliki kemandirian dalam belajar. Bukan menguasai siswa; (d) sekolah adalah miniature kehidupan dimana dalam masyara- kat. Karena itu pendidikan akan bermakna bila pendidikan itu bermanfaat dalam kehidupan masyarakat; (e) aktivitas belajar lebih berfokus pada pemecahan masalah, bukan sekedar menghafal dan menguasai materi pelajaran; (f) iklim belajar harus demokratis dan kooperatif, karena setiap individu pasti akan hidup bersama orang lain, maka setiap orang harus mampu bekerja sama dengan orang lain (Kuntoro, 2008, pp. 6-7). Prinsip pendidikan humanis akan berjalan dengan efektif jika guru sebagai pendidik sudah mencerminkan perilaku yang humanis. Perilaku pendidik yang humanis terbentuk oleh budaya sekolah yang humanis.

Tujuan pendidikan yang humanis adalah membangun tiga kekuatan dalam diri individu secara sinergis. Pertama, individu perlu untuk mengembangkan power to yakni kekuatan kreatif yang membuat seseorang mampu dan mau untuk melakukan sesuatu. Kedua, Power with, membangun solidaritas atas dasar komitmen pada tujuan yang sama guna memecahkan permasalahan yang dihadapi dan menciptakan kesejahteraan bersama. Ketiga, Power with in, kekuatan spiritual yang ada dalam diri anak didik guna membuat manusia menjadi lebih manusiawi (Sastrapratedja, 2009 dalam Hibana 2012).

Untuk membangun kekuatan dalam diri individu memerlukan seorang pendidik yang humanis. Dalam konteks inilah, seorang pendidik haruslah menyadari bahwa mendidik adalah proses sosial yang sangat bermakna dan sebagai aktivitas kehidupan yang sangat mulia. Kesalahan dalam proses mendidik dapat melemahkan dan menghancurkan kekuatan yang dimiliki oleh individu untuk belajar. Oleh karena itu, proses belajar harus dimaknai sebagai proses untuk membangun "power" yang sangat diperlukan oleh manusia untuk bisa bertahan dan mengembangkan dirinya sebagai manusia yang bebas berekspresi, bereksistensi dan beradaptasi dalam menghadapi kehidupan yang sangat membutuhkan kecepatan untuk belajar.

Kesulitan dalam belajar dapat bersumber dari melemahnya kekuatan yang dimiliki oleh peserta didik. Guru mempunyai peran untuk membangun kekuatan belajar dalam diri peserta didik. Cara guru untuk menguatkan kekuatan belajar peserta didik dengan cara: a) menyadarkan peserta didik bahwa setiap individu diberikan kemampuan 
berpikir yang mampu menggerakkan daya kreatif dan imajinatif untuk menjadi manusia yang produktif, b) membekali peserta didik untuk menjadi individu yang mampu bekerjasama dan bertanggung jawab yang dilandasi oleh nilai komitmen; c) membentuk peserta didik sebagai manusia yang memliki kekuatan spritual. Dengan demikian, kesulitan belajar dapat diatasi oleh guru yang humanis yang secara profesional mampu mendorong peserta didik berperilaku humanis. Guru akan optimal dalam membangun fondasi pendidikan humanis, jika sekolah menerapkan prinsip-prinsip yang diperlukan dalam pelaksanakan pendidikan yang humanis.

Dengan demikian, pelaksanaan pendidikan humanis bermakna apabila apa yang dipelajari berdampak pada pengembangan diri. Dengan demikian pengetahuan guru harus sesuai dengan minat dan kebutuhan peserta didik. Proses belajar harusnya dapat menghilangkan situasi yang mengandung paksaan dan tekanan, dan membangun komunikasi dua arah, sehingga dapat menjadikan struktur diri individidu terbuka, dan dapat menerima informasi secara lebih optimal yang melahirkan pemberdayaan terhadap peserta didik sehingga mampu menggali potensi dan bakatnya secara sendiri dan mandiri, tanpa harus terlalu dipandu sedemikian ketat oleh pendidik.

\section{Guru Humanis: Profesional dan Berkarakter}

Guru yang tidak profesional tak akan mampu berkembang menjadi pribadi yang berkarakter. Guru yang profesional harus mampu menjalankan multiperan dengan sinergis (Baskoro, 2006 dalam Dwingrum 2012). Profesionalisme ditentukan oleh kemampuan untuk mengembangkan pribadi yang memiliki kekuatan moral yang positip sebagai model di kelas. Guru yang profesional memiliki nilainilai karakter yang melekat dalam kepribadiannya. Multiperan guru dapat dijabarkan sebagaimana disajikan pada Tabel 1.

Tabel 1. Multiperan Guru

\begin{tabular}{|c|c|c|}
\hline Kedudukan & Nilai & Perilaku \\
\hline Kedudukan & 1. Self esteem & a. memiliki harga diri sebagai guru. \\
\hline \multirow[t]{8}{*}{ Pribadi } & 2. Vision & b. memiliki pandangan, wawasan, dan atau cita-cita. \\
\hline & 3. Commitment & c. memiliki kepeduliaan dan kemauan yang keras untuk melaksanakan \\
\hline & 4. Conviction & tugasnya sebagai guru. \\
\hline & 5. Aspiration & d. memiliki keyakinan diri atau percaya diri untuk melaksanakan tugasnya \\
\hline & 6. Dignity & dengan baik. \\
\hline & 7. Creative & e. keinginan diri tentang sesuatu yang dicita-citakan dalam melaksanakan \\
\hline & 8. Fun-Humoris & tugasnya. \\
\hline & & $\begin{array}{l}\text { f. memiliki harkat dan martabat sebagai pendidik untuk melaksanakan } \\
\text { tugasnya sesuai dengan ketentuan moral dan hukum yang berlaku. } \\
\text { g. memiliki kemampuan untuk berkreasi, inovatif dll } \\
\text { h. Menyenangkan }\end{array}$ \\
\hline Kedudukan & Responsibility: & a. memiliki rasa tanggung jawab yang tinggi untuk melaksanakan \\
\hline \multirow[t]{9}{*}{ Profesional } & Autonomy & tugasnya dengan sebaik-baiknya. \\
\hline & Accountability & b. memiliki kemandirian untuk melaksanakan tugasnya. \\
\hline & Competence & c. memiliki rasa tanggung jawab terhadap proses dan hasil dalam \\
\hline & Knowlegde & melaksanakan tugasnya. \\
\hline & Teacher Research & d. memiliki kompetensi dalam melaksanakan tugasnya sesuai dengan \\
\hline & Publications & tandar yang telah ditentukan. \\
\hline & $\begin{array}{l}\text { Participative } \\
\text { management }\end{array}$ & $\begin{array}{l}\text { e. memiliki pengetahuan yang luas dan keahlian untuk dapat mengemban } \\
\text { tugasnya. }\end{array}$ \\
\hline & & $\begin{array}{l}\text { f. merancang dan melaksanakan penelitian tentang pelaksanaan tugasnya } \\
\text { atau menerbitkan tulisan atau hasil pelaksanaan tugasnya kepada publik. }\end{array}$ \\
\hline & & $\begin{array}{l}\text { g. menyampaikan laporan tentang pelaksanaan tugasnya kepada publik. } \\
\text { h. berperan serta aktif dalam kegiatan yang terkait dengan pendidikan dan } \\
\text { guru. }\end{array}$ \\
\hline Kedudukan & Salary Minimum & a. menerima gaji yang memadai dan sesuai dengan beban tugasnya. \\
\hline \multirow[t]{2}{*}{ Sosial } & working standart & b. memperoleh standar kerja yang layak dengan statusnya. \\
\hline & $\begin{array}{l}\text { Welfare and } \\
\text { fringe benefits }\end{array}$ & $\begin{array}{l}\text { c. memperoleh kesejahteraan yang memadai dan intensif tambahan yang } \\
\text { wajar sesuai dengan tanggung jawabnya sebagai guru. }\end{array}$ \\
\hline
\end{tabular}


Tabel 2. Empat Kompetensi Guru

\begin{tabular}{ll}
\hline Kompetensi & Kemampuan \\
\hline Pedagogik & Guru dalam pengelolaan pembelajaran mempunyai 7 kemampuan yaitu: memahami latar \\
& belakang siswa; memahami teori belajar; pengembangan kurikulum; aktivitas pengembangan \\
& pendidikan; peningkatan potensi siswa; berkomunikasi dengan siswa, penilaian dan evaluasi \\
Kepribadian & Guru mempunyai kepribadian yang beriman dan bertakwa; berakhlak mulia; arif dan \\
& bijaksana; demokratis; mantap; berwibawa; stabil; dewasa; jujur; sportif; menjadi teladan bagi \\
& peserta didik dan masyarakat; sportif; menjadi teladan bagi peserta didik dan masyarakat; \\
& secara obyektif mengevaluasi kinerja sendiri; dan mengembangkan diri secara mandiri dan \\
& berkelanjutan \\
& Guru sebagai bagian dari Masyarakat yang sekurang-kurangnya meliputi kemampuan untuk: \\
& berkomunikasi lisan, tulis, dan/atau isyarat secara santun; \\
& menggunakan teknologi komunikasi dan informasi secara fungsional; bergaul secara efektif \\
& dengan peserta didik, sesama pendidik, tenaga kependidikan, pimpinan satuan pendidikan, \\
& orang tua atau wali peserta didik; bergaul secara santun dengan masyarakat sekitar dengan \\
& mengindahkan norma serta sistem nilai yang berlaku; dan menerapkan prinsip persaudaraan \\
& sejati dan semangat kebersamaan \\
& Guru mempunyai kemampuan untuk menguasai pengetahuan bidang ilmu pengetahuan, \\
& teknologi, dan/atau seni dan budaya yang diampunya yang sekurang-kurangnya meliputi \\
& penguasaan: materi pelajaran secara luas dan mendalam sesuai dengan standar isi program \\
& satuan pendidikan, mata pelajaran, dan/atau kelompok mata pelajaran yang akan diampu; dan \\
& konsep dan metode disiplin keilmuan, teknologi,atau seni yang relevan, yang secara \\
& konseptual menaungi atau koheren dengan program satuan pendidikan, mata pelajaran, \\
dan/atau kelompok mata pelajaran yang akan diampu
\end{tabular}

Tabel 3. Prinsip Belajar Humanis

\begin{tabular}{|c|c|}
\hline Prinsip Belajar & Deskripsi \\
\hline $\begin{array}{l}\text { Hasrat untuk } \\
\text { Belajar }\end{array}$ & $\begin{array}{l}\text { Manusia mempunyai hasrat alami untuk belajar. Hal ini terbukti dengan tingginya rasa ingin tahu } \\
\text { anak apabila diberi kesempatan untuk mengeksplorasi lingkungan. Dorongan ingin tahu untuk } \\
\text { belajar ini merupakan asumsi dasar pendidikan humanistik. Di dalam kelas yang humanistik } \\
\text { anak-anak diberi kesempatan dan kebebasan untuk memuaskan dorongan ingin tahunya, untuk } \\
\text { memenuhi minatnya dan untuk menemukan apa yang penting dan berarti tentang dunia di } \\
\text { sekitarnya. }\end{array}$ \\
\hline $\begin{array}{l}\text { Belajar yang } \\
\text { Berarti }\end{array}$ & $\begin{array}{l}\text { Belajar mempunyai arti atau makna apabila apa yang dipelajari relevan dengan kebutuhan dan } \\
\text { maksud anak. Artinya, anak akan belajar dengan cepat apabila yang dipelajari mempunyai arti } \\
\text { baginya. }\end{array}$ \\
\hline Belajar Tanpa & Belajar mudah dilakukan dan hasilnya dapat disimpan dengan baik apabila berlangsung dalam \\
\hline Ancaman & $\begin{array}{l}\text { lingkungan yang bebas ancaman. Proses belajar akan berjalan lancar jika murid dapat menguji } \\
\text { kemampuannya, dapat mencoba pengalaman-pengalaman baru atau membuat kesalahan- } \\
\text { kesalahan tanpa mendapat kecaman yang bisaanya menyinggung perasaan. }\end{array}$ \\
\hline $\begin{array}{l}\text { Belajar atas } \\
\text { Inisiatif }\end{array}$ & $\begin{array}{l}\text { Belajar paling bermakna jika dilakukan atas inisiatif sendiri dan melibatkan perasaan dan pikiran } \\
\text { si pelajar. Mampu memilih arah belajarnya sendiri sangatlah memberikan motivasi dan }\end{array}$ \\
\hline Sendiri & $\begin{array}{l}\text { mengulurkan kesempatan kepada murid untuk "belajar bagaimana caranya belajar" (to learn how } \\
\text { to learn ). Belajar paling bermakna menguasai bahan pelajaran itu penting, akan tetapi tidak lebih } \\
\text { penting daripada memperoleh kecakapan untuk mencari sumber, merumuskan masalah, menguji } \\
\text { hipotesis atau asumsi, dan menilai hasil serta memusatkan perhatian murid baik pada proses } \\
\text { maupun hasil belajar. Belajar atas inisiatif sendiri memiliki kesempatan untuk menimbang- } \\
\text { nimbang dan membuat keputusan, menentukan pilihan dan melakukan penilaian. Dia menjadi } \\
\text { lebih bergantung pada dirinya sendiri dan kurang bersandar pada penilaian pihak lain. }\end{array}$ \\
\hline Belajar dan & Prinsip terakhir yang dikemukakan oleh Rogers ialah bahwa belajar yang paling bermanfaat ialah \\
\hline Perubahan & $\begin{array}{l}\text { bejar tentang proses belajar. Menurut Rogers, di waktu-waktu yang lampau murid belajar } \\
\text { mengenai fakta-fakta dan gagasan-gagasan yang statis. Waktu itu dunia lambat brerubah, dan apa } \\
\text { yang diperoleh di sekolah sudah dipandang cukup untuk memenuhi tuntutan zaman. Saat ini } \\
\text { perubahan merupakan fakta hidup yang sentral. Ilmu Pengetahuan dan Teknologi selalu maju dan } \\
\text { melaju. Apa yang dipelajari di masa lalu tidak dapat membekali orang untuk hidup dan berfungsi } \\
\text { baik di masa kini dan masa yang akan dating. Dengan demikian, yang dibutuhkan saat ini adalah } \\
\text { orang yang mampu belajar di lingkungan yang sedang berubah dan akan terus berubah }\end{array}$ \\
\hline
\end{tabular}


Dari paparan Tabel 1 dapat disimpulkan bahwa menjadi guru sesungguhnya tidak mudah. Seorang guru dituntut untuk memiliki nilai-nilai pokok yang mendasari perilakunya dalam menjalankan perannya. Jika guru dapat menjalankan seluruh multiperan secara optimal, maka guru akan mudah untuk memenuhi empat standar kompetensi guru yang ditetapkan oleh pemerintah tentang Guru yang profesional di tuntut untuk memiliki empat kompetensi seperti yang telah diamanatkan dalam UU No 14 Th 2005 tentang Guru dan Dosen serta PP No. 74 tentang Guru. Kompetensi adalah seperangkat pengetahuan, keterampilan, dan perilaku yang harus dimiliki, dihayati, dan dikuasai oleh guru dalam melaksanakan tugas keprofesionalan. Empat kompetensi yang dimaksud disajikan pada Tabel 2.

Kompetensi guru tidak cukup dipahami dari aspek-aspek normatif yang melekat dalam kerpibadian guru, karena untuk menghasilkan proses belajar yang optimal, khususnya untuk membentuk prinadi siswa yang humanis perlu dipahami pengetahuan pendidikan yang humanis. Menurut Carl Rogers guru harus memahami prinsip humanistik, yakni intinya guru memberikan kebebasan dan dukungan emosional untuk bertumbuh dan berkembang menjadi manusia yang berfungsi secara penuh kepada peserta didik. Untuk mendapatkan hasil yang maksimal dalam proses belajar humanis, Rogers memberikan beberapa prinsip belajar humanis yang harus dipahami oleh para pendidik dalam mengajar di kelas (Mahfud, p.2012) yang disajikan pada Tabel 3.

Berdasarkan paparan Tabel 3 dapat disimpulkan bahwa proses belajar adalah proses yang sangat komplek karena dalam belajar selalu terkait dengan semua aspek kepribadian dari aspek kognitif maupun afektif, sebagaimana dikatakan oleh Rogers bahwa belajar digambarkan sebagai whole-personlearning, belajar dengan seluruh pribadi, belajar dengan pribadi yang utuh. Para ahli humanistik percaya, bahwa belajar dengan tipe ini akan menghasilkan perasaan memiliki (feeling of belonging ) pada diri peserta didik. Dengan demikian, murid akan merasa terlibat dalam belajar, lebih bersemangat menangani tugastugas dan yang terpenting adalah senantiasa bergairah untuk terus belajar. Dalam kontek inilah, guru yang profesional menyadari pentingnya membangun belajar dan sekolah yang humanis. Siswa cenderung lebih aktif dan dihargai eksistensinya di kelas. Di samping itu, siswa akan merasakan dinamika dalam pribadinya, karena aktivitas yang dirancang oleh guru memberikan makna dalam hidupnya. Peran guru menjadi sangat penting dalam proses pencarian makna dalam kehidupan oleh peserta didik. Dengan demikian, pekerjaan guru tidak cukup dibatasi oleh profesionalisme sebagai prasyarat normatif, tetapi sangat ditentukan oleh kekuatan keprofesionalisme guru sebagai energi sosial yang dibutuhkan untuk menjalankan tanggung jawab dan integritasnya sebagai pendidik.

Integritas pendidik diperlukan dalam menghadapi tantangan dan dinamika pembangunan pendidikan. Oleh karenanya, akuntabilitas profesional diperlukan bagi guru untuk mencerminkan kompetensi dan integritas pendidik. Sebagaimana dijelaskan oleh John Tomlinson dan Vivianne Little yang mengaitkan etika dengan masalah epistemologis dan tujuan profesional (2005, p. 4 dalam Haryatmoko 2013) yang menjelaskan empat disposisi dalam proses belajar-mengajar, Pertama, semua afrimasi dapat didiskusikan. Tidak ada norma/nilai yang tidak dapat diperdebatkan, yang tidak bisa dipertanyakan atau dikritik. Argumentasi menjadi satu-satunya dasar pengambilan keputusan atau dasar persetujuan. Semua peretujuan bisa pertanyakan bila ada argumentasi baru. Ke dua, disposisi untuk memperjuangkan kepentingan peserta didik. Memberi kesempatan semua peserta didik untuk belajar, meraih kesempatan, tanggung jawab dan pengalam hidup untuk kesejahteraan mereka di masa depan. Ketiga, disposisi untuk rendah hati karena pengetahuan selalu berkembang, kebenaran ilmu pengetahuan sifatmya sementara, maka akan ada selalu ada penemuan batu yang mempertanyakan kebenaran yang ada. Keempat, prinsip "bisa salah" berlaku untuk semua pihak yang terlibat di dalam kemitraan pendidikan. Dengan menerima prinsip itu, guru memiliki profesionalisme yang kuat untuk tetap setiap dalam mewujudkan tujuan pendidikan. Dalam menghadapi persoalan yang komplek terkait dengan pembangunan pendidikan, profesionalisme harus diperhatahankan dengan terus memupuk kehendak secara terusmenerus, apapun tekanannya, yang mengarahkan pada konformitas terhadap kurikulum maupun tujuan pendidikan yang hendak di- 
capai. Akhirnya, tulisan ini belum selesai untuk mengkaji membangun belajar yang humanis, karena belajar adalah proses sepanjang manusia hidup yang dinamikanya tetap menarik untuk dikaji dan diteliti untuk mencari formula yang paling sesuai dengan perubahan sosial-budaya yang tetap membutuhkan manusia untuk terur-terus belajar. Dengan tulisan ini diharapkan dapat digunakan oleh kita sebagai pendidik untuk terus menjadi ujung tombak dalam membangun belajar yang humanis dalam kehidupan sosial yang tak pernah berhenti untuk terus belajar.

\section{KESIMPULAN}

Dehumanisasi pendidikan merupakan masalah yang mendasar dalam pembanguan pendidikan nasional. Sistem pendidikan nasional belum memberikan kesempatan pada peserta didik untuk mengembangkan potensi dirinya secara optimal; kurang menumbuhkan nilai-nilai kemanusiaan; dan melemahnya penanaman nilai etika dan estetika peserta didik. Dehumanisasi disebabkan oleh banyak faktor antara lain adalah: krisis karakter bangsa terjadi dalam dunia pendidikan, aktivitas kelembagaan pendidikan yang pragmatis materialistik, perilaku sosial yang cenderung ke arah menghancurkan diri bangsa kita sendiri (act of self distruction), ketidakadilan dalam proses pendidikan sebagai gejala dehumanisasi struktural, arogansi kekuasaan yang menghambat kreativitas dan kebebasan peserta didik untuk berekspresi, mentalitas lemah dan tidak memiliki kemandirian.

Dehumanisasi pendidikan dapat diatasi dengan menciptakan belajar yang humanis. Belajar yang humanis fondasi pendidikan humanis dalam sistem pendidikan nasional Pendidikan humanis yang bertujuan menyempurnakan kemanusiaan. Proses belajar humanis ditujukan untuk menghilangkan situasi yang mengandung paksaan dan tekanan, dan membangun komunikasi dua arah, sehingga dapat menjadikan struktur diri individidu terbuka, dan dapat menerima informasi secara lebih optimal. Belajar yang humanis memberdayakan potensi dan bakat secara optimal sehingga terbentuk individu yang mandiri Demikian halnya, dalam proses pembelajaran di kelas pendidik harus benar-benar memahami prinsip-prinsip dalam pendidik humanistik.
Sekolah harus dibangun dalam landasan pendidikan humanis yang didukung oleh guru-guru humanis yang memiliki akuntabilitas profesional. Guru yang profesional dan berkarakter akan mampu menciptakan sekolah yang berbudaya humanis. Guru mempunyai peran untuk membangun kekuatan belajar dalam diri peserta didik. Cara guru untuk menguatkan kekuatan belajar peserta didik dengan cara: menyadarkan peserta didik bahwa setiap individu diberikan kemampuan berpikir yang mampu menggerakkan daya kreatif dan imajinatif untuk menjadi manusia yang produktif; membekali peserta didik untuk menjadi individu yang mampu bekerjasama dan bertanggung jawab yang dilandasi oleh nilai komitmen; dan membentuk peserta didik sebagai manusia yang memliki kekuatan spritual. Dengan demikian, kesulitan belajar dapat diatasi oleh guru yang humanis yang secara profesional mampu mendorong peserta didik berperilaku humanis.

\section{DAFTAR PUSTAKA}

Dwiningrum, S. I. A. (2010). Pendekatan holistik dan kontekstual dalam mengatasi krisis karakter di indonesia. dalam Cakrawala Pendidikan, Yogyakarya, UNY, Mei 2010, Th. XXIX, Edisi Khusus Dies Natalis.

Dewey, J. (1963). Experience and education, New York: Collier Books. A Devision of Macmillan Publishing Co.Inc.

Hibana (2013), Pengembangan pendidikan humanis religius di sekolah madarsah, Yogyakarta: Progam Ilmu Pendidikan S3, PPs UNY

Kuntoro, S. A. (2008). Sketsa pendidikan humanis religius. Pascasarjana; UNY

Raka, G. (2006). Guru tranformasional dalam pembangunan karakter dan pembangunan bangsa. Makalah, Orasi Dosen Berpretasi Tingkat Poltekes dan Tingkat Nasional, Jakarta: 10 Nopember 2006.

Raka, G.(2006), Pendidikan untuk kehidupan bermakna. Makalah, Orasi Ilmiah pada Hari Wisuda Universitas Kristen Maranatha Bandung, 25 Maret 2006. 
Raka, G. (2007), Pendidikan membangun karakter, Makalah, Orasi Perguruan Taman Siswa, Bandung 10 Februari 2007.

Rosen, F. B. (1998), Sistem-sistem filsafat pendidikan. diterjemahkan oleh A. Sudiarjo, SJ, Yogyakarta: Univessitas Sanata Dharma.

Sastrapratedja, M. (2009), Pendidikan sebagai humanisasi. Yogyakarta: Universitas Sanata Dharma

Sastrapratedja, M. (2012). Untuk membangun humanisme sebagai prinsip pendidikan, disampaikan dalam Kongres Pendidikan dan Pengajaran dan Kebudayaan, Balai Senat UGM Yogyakarta

Dimyati \& Mudjiono. (1999). Belajar dan pembelajaran. Jakarta: Rineka Cipta

Slameto. (2003). Belajar dan faktor-faktor yang mempengaruhinya. Jakarta: Rineka Cipta

Hakim, T. (2005). Belajar secara efektif. Jakarta: Puspa Swara

Salkind, NJ (2004), An Introduction to theories of human development, USA: Sage Publication, Inc. 